\title{
Realization of entry-to-practice milestones by Canadians who studied medicine abroad and other international medical graduates: a retrospective cohort study
}

\author{
Maria Mathews PhD, Rima Kandar MSc, Steve Slade MA, Yanqing Yi PhD, Sue Beardall MHSc, \\ Ivy Bourgeault $\mathrm{PhD}$
}

\section{Abstract}

Background: International medical graduates must realize a series of milestones to obtain full licensure. We examined the realization of milestones by Canadian and non-Canadian graduates of Western or Caribbean medical schools, and Canadian and nonCanadian graduates from other medical schools.

Methods: Using the National IMG Database (data available for 2005-2011), we created 2 cohorts: 1) international medical graduates who had passed the Medical Council of Canada Qualifying Examination Part I between 2005 and 2010 and 2) those who had first entered a family medicine postgraduate program between 2005 and 2009 , or had first entered a specialty postgraduate program in 2005 or 2006. We examined 3 entry-to-practice milestones; obtaining a postgraduate position, passing the Medical Council of Canada Qualifying Examination Part II and obtaining a specialty designation.

Results: Of the 6925 eligible graduates in cohort 1, 2144 (31.0\%) had obtained a postgraduate position. Of the 1214 eligible graduates in cohort 2, 1126 (92.8\%) had passed the Qualifying Examination Part II, and $889(73.2 \%)$ had obtained a specialty designation. In multivariate analyses, Canadian graduates of Western or Caribbean medical schools (odds ratio [OR] 4.69, 95\% confidence interval [Cl] 3.82-5.71) and Canadian graduates of other medical schools (OR 1.49, 95\% Cl 1.31-1.70) were more likely to obtain a postgraduate position than non-Canadian graduates of other (not Western or Caribbean) medical schools. There was no difference among the groups in passing the Qualifying Examination Part II or obtaining a specialty designation.

Interpretation: Canadians who studied abroad were more likely than other international medical graduates to obtain a postgraduate position; there were no differences among the groups in realizing milestones once in a postgraduate program. These findings support policies that do not distinguish postgraduate applicants by citizenship or permanent residency status before medical school.

I nternational medical graduates are physicians who, regardless of citizenship, graduated from medical school outside of Canada. To obtain full licensure, international medical graduates must have their educational credentials verified and pass language proficiency tests and 3 Medical Council of Canada examinations (Evaluating Examination, Qualifying Examination Part I and Qualifying Examination Part II). ${ }^{1}$ They must also pass examinations to obtain specialist credentials (Certificant of the College of Family Physicians, Fellow of the Royal College of Physicians of Canada, Fellow of the Royal College of Surgeons of Canada). ${ }^{1,2}$ To write the Qualifying Examination Part II and specialty examinations, international medical graduates must have recognized clinical experience; those who do not must complete postgraduate training (usually residency training). Obtaining a residency position is the greatest obstacle to full licensure because there are more applicants than positions available to international medical graduates. ${ }^{3-11}$ The term "international medical graduate" includes Canadian citizens or permanent residents who studied medicine abroad. ${ }^{9}, 12,13$ Canadians who studied abroad appear to be more successful

Competing interests: The authors work for organizations involved in international medical graduate training (Maria Mathews, Yanqing Yi, Ivy Bourgeault) and the development of monitoring policies related to physician credentialling and training (Rima Kandar, Steve Slade, Sue Beardall). No other competing interests were declared.

This article has been peer reviewed.

Correspondence to: Maria Mathews, mmathews@mun.ca

CMAJ Open 2017. DOI:10.9778/cmajo.20160144 
than other international medical graduates in obtaining a residency position in Canada. ${ }^{8,14}$

This study responds to calls for more information about the performance of all international medical graduates at the various stages of the credentialling and licensing process. ${ }^{3,15}$ The study objective was to compare the realization by Canadians who studied abroad and other international medical graduates of 3 milestones: obtaining a postgraduate training position, passing the Medical Council of Canada Qualifying Examination Part II and obtaining a specialist designation. We hypothesized that Canadians who studied abroad would be more successful in realizing these milestones than other international medical graduates.

\section{Methods}

\section{Sources of data}

We used the Canadian Post-M.D. Education Registry's National IMG Database, which includes data from agencies involved in the training, assessment, certification and licensing of physicians. ${ }^{16}$ Data were available for international medical graduates in all provinces and territories except Prince Edward Island, the Northwest Territories and Nunavut. The database is the most complete and comprehensive data set on international medical graduates in Canada, with data from 2005 to 2011 (funding to maintain the original database beyond this period was not available).

\section{Primary measurements/outcomes}

Using a cohort study design, we examined 3 outcomes: obtained a postgraduate position (residency or fellowship) (yes/no), passed the Medical Council of Canada Qualifying Examination Part II (yes/no) and obtained a specialty designation (yes/no). We included both residency and fellowship training because fellowship (additional years of training that normally follow residency) qualifies as recognized clinical experience that enables international medical graduates to write the Qualifying Examination Part II and specialty examinations. Examination data were reported to the National IMG Database by the Medical Council of Canada, the College of Family Physicians of Canada and the Royal College of Physicians and Surgeons of Canada. The database includes the year in which an international medical graduate passed the Qualifying Examination Part II and the year in which he or she was awarded a specialty designation; it does not include whether a graduate wrote or failed the examination. In our analyses, we assumed that all international medical graduates would attempt to obtain full licensure (i.e., if graduates realized 1 milestone, they would attempt to realize subsequent milestones), since a full licence would allow them to practise independently and in the location of their choice.

We defined Canadians who studied abroad as international medical graduates who were Canadian citizens or permanent residents before entering medical school. We identified Canadian citizens and residents based on birth place and legal status in Canada reported by multiple agencies to the National IMG Database. Preliminary analyses, corroborated by consultations with medical educators, suggested that physicians who graduated from medical schools in Western (United Kingdom, Ireland, Western Europe, New Zealand or Australia) or Caribbean countries may have different outcomes than physicians who graduated from non-Western, non-Caribbean medical schools. We therefore created an independent variable that captured both legal status and training site, and examined 4 groups in the study:

- Canadian (citizens/permanent residents) graduates of Western or Caribbean medical schools

- Canadian (citizens/permanent residents) graduates of other (not Western or Caribbean) medical schools

- Non-Canadian graduates of Western or Caribbean medical schools

- Non-Canadian graduates of other (not Western or Caribbean) medical schools.

Covariates were age, sex, participation in a skills-assessment/ training program and, where applicable, specialty and first rank. ${ }^{3,17}$ Because birthdate was not available for all international medical graduates, we calculated the difference between year of medical school graduation and year of realizing a standard reference (passing the Medical Council of Canada Qualifying Examination Part I or, if applicable, entering postgraduate training) to create comparable age categories. We coded age as younger ( -5 to $5 \mathrm{yr}$ between graduating from medical school and reference event) or older ( $\geq 6 \mathrm{yr}$ between graduating from medical school and reference event).

\section{Sample}

Because the National IMG Database covers a 7-year period (2005-2011) and few international medical graduates would have been able to complete all the steps (from Medical Council of Canada Evaluating Examination to specialty examination) needed for full licensure during that time, we examined 2 separate cohorts in the study. For the outcome "obtained postgraduate position," physicians had to have passed the Qualifying Examination Part I between 2005 and 2010; this time cut-off allowed physicians at least 1 year to obtain a postgraduate position. For the outcomes "passed Medical Council of Canada Qualifying Examination Part II" and "obtained specialty designation," physicians had to have first entered a family medicine postgraduate program between 2005 and 2009 , or have first entered a specialty postgraduate program in 2005 or 2006. These cut-off periods allowed sufficient time to qualify for the Qualifying Examination Part II, complete programs and write the applicable specialty examinations. We excluded international medical graduates who first entered postgraduate programs before these dates because they may have passed the Qualifying Examination Part II before 2005 (i.e., before the start of the database). The Canadian PostM.D. Education Registry data submitted to the National IMG Database extend back to 1988 and allowed us to determine the first and last years in postgraduate training.

We excluded graduates of US medical schools because a number of Canadian agencies treat them as Canadian medical graduates. ${ }^{14,18} \mathrm{We}$ excluded visa trainees because they are expected to return to their home country after training and may not write examinations expected of other international medical graduates. ${ }^{19,20}$ 


\section{OPEN}

Research

\section{Statistical analysis}

We described the characteristics of the sample using SPSS version 23.0 and used $\chi^{2}$ tests to determine the association between each outcome and relevant predictors. We used multiple logistic regression to identify significant $(p<0.05)$ predictors for each outcome. We selected potential covariates for each regression model on the basis of the $\chi^{2}$ tests. A priori examination showed that none of the variables were highly correlated. We removed predictors from the model if they were not significant (based on the Wald test) and did not significantly improve the change in the -2 log-likelihood value. ${ }^{21}$ The tables list the variables included in the final regression models.

\section{Ethics approval}

The Newfoundland and Labrador Health Research Ethics Board approved this study.

\section{Results}

Between 2005 and 2010,6925 international medical graduates passed the Qualifying Examination Part I and were included in the cohort for the outcome "obtained postgraduate position." Almost one-third (2144 [31.0\%]) of the graduates entered a postgraduate training program (Table 1).

\begin{tabular}{|c|c|c|}
\hline \multirow[b]{2}{*}{ Characteristic } & \multicolumn{2}{|c|}{ No. $(\%)$ of graduates } \\
\hline & $\begin{array}{l}\text { Cohort } 1 \\
n=6925\end{array}$ & $\begin{array}{l}\text { Cohort } 2 \\
n=1214\end{array}$ \\
\hline \multicolumn{3}{|l|}{ Milestone } \\
\hline Obtained postgraduate position & 2144 (31.0) & - \\
\hline $\begin{array}{l}\text { Passed Medical Council of Canada } \\
\text { Qualifying Examination Part II }\end{array}$ & - & $1126(92.8)$ \\
\hline Obtained specialty designation & - & 889 (73.2) \\
\hline \multicolumn{3}{|l|}{ Type of international medical graduate } \\
\hline $\begin{array}{l}\text { Canadian graduate of Western or } \\
\text { Caribbean medical school }\end{array}$ & $649(9.4)$ & $196(16.1)$ \\
\hline $\begin{array}{l}\text { Canadian graduate of other medical } \\
\text { school }\end{array}$ & 1375 (19.9) & $382(31.5)$ \\
\hline $\begin{array}{l}\text { Non-Canadian graduate of Western or } \\
\text { Caribbean medical school }\end{array}$ & $229(3.3)$ & $25(2.0)$ \\
\hline $\begin{array}{l}\text { Non-Canadian graduate of other } \\
\text { medical school }\end{array}$ & $4672(67.5)$ & $611(50.3)$ \\
\hline \multicolumn{3}{|l|}{ Sex } \\
\hline Female & $3185(46.0)$ & $673(55.4)$ \\
\hline Male & $3739(54.0)$ & $541(44.6)$ \\
\hline Missing & $1(0.0)$ & $0(0.0)$ \\
\hline \multicolumn{3}{|l|}{ Age } \\
\hline Younger & $2329(33.6)$ & $462(38.0)$ \\
\hline Older & $4562(65.9)$ & $752(61.9)$ \\
\hline Unknown & $34(0.5)$ & $0(0.0)$ \\
\hline Had skills assessment & $2482(35.8)$ & $302(24.9)$ \\
\hline \multicolumn{3}{|l|}{ Specialty type } \\
\hline Family medicine & $880(12.7)$ & $852(70.2)$ \\
\hline Specialist & 1264 (18.2) & $362(29.8)$ \\
\hline Unknown & $4781(69.0)$ & $0(0.0)$ \\
\hline \multicolumn{3}{|l|}{ First rank } \\
\hline Resident & - & $1123(92.5)$ \\
\hline Fellow & - & $91(7.5)$ \\
\hline
\end{tabular}


In unadjusted analyses, compared to international medical graduates who did not obtain a postgraduate position, a larger proportion of graduates who obtained a postgraduate training position were Canadians who had graduated from Western or Caribbean medical schools, were Canadians who had graduated from other medical schools, were women and were younger $(p<0.001)$ (Table 2$)$. After other significant predictors (sex, age, had skills assessment, type of international medical graduate, specialty type and first rank) were controlled for, men were 0.74 (95\% confidence interval [CI] 0.66-0.82) times as likely as women to obtain a postgraduate position (Table 3). Younger graduates were 1.77 (95\% CI 1.57-2.00) times more likely to obtain a postgraduate position than older graduates. Those who had participated in a skills assessment/ training program were 1.15 (95\% CI 1.02-1.29) times more likely to obtain a postgraduate position than those who had not. Canadians who had graduated from Western or Caribbean medical schools and Canadians who had graduated from other medical schools were 4.69 (95\% CI 3.82-5.71) and 1.49 (95\% CI 1.31-1.70) times more likely, respectively, to obtain a postgraduate position than non-Canadian physicians who had graduated from other medical schools.

In the second cohort, there were 1214 international medical graduates who had first entered a family medicine post-

\begin{tabular}{|c|c|c|c|c|c|c|c|c|c|}
\hline \multirow[b]{3}{*}{ Characteristic } & \multicolumn{9}{|c|}{ Milestone; no. (\%) of graduates } \\
\hline & \multicolumn{2}{|c|}{$\begin{array}{l}\text { Obtained postgraduate } \\
\text { position* }^{\star}\end{array}$} & \multirow[b]{2}{*}{$p$ value } & \multicolumn{2}{|c|}{$\begin{array}{c}\text { Passed Qualifying } \\
\text { Examination Part II† } \\
n=1126\end{array}$} & \multirow[b]{2}{*}{$p$ value } & \multicolumn{2}{|c|}{$\begin{array}{c}\text { Obtained specialty } \\
\text { designation } \dagger \\
n=889\end{array}$} & \multirow[b]{2}{*}{$p$ value } \\
\hline & Yes & No & & Yes & No & & Yes & No & \\
\hline \multicolumn{10}{|l|}{$\begin{array}{l}\text { Type of international } \\
\text { medical graduate }\end{array}$} \\
\hline $\begin{array}{l}\text { Canadian graduate of } \\
\text { Western or Caribbean } \\
\text { medical school }\end{array}$ & $430(20.1)$ & $219(4.6)$ & $<0.001$ & $180(16.0)$ & $16(18.2)$ & 0.3 & $158(17.8)$ & $38(11.7)$ & 0.01 \\
\hline $\begin{array}{l}\text { Canadian graduate of } \\
\text { other medical school }\end{array}$ & $486(22.7)$ & $889(18.6)$ & & $362(32.1)$ & $20(22.7)$ & & $280(31.5)$ & $102(31.4)$ & \\
\hline $\begin{array}{l}\text { Non-Canadian graduate } \\
\text { of Western or Caribbean } \\
\text { medical school }\end{array}$ & $55(2.6)$ & $174(3.6)$ & & $23(2.0)$ & $2(2.3)$ & & $22(2.5)$ & $3(0.9)$ & \\
\hline $\begin{array}{l}\text { Non-Canadian graduate } \\
\text { of other medical school }\end{array}$ & $1173(54.7)$ & $3499(73.2)$ & & $561(49.8)$ & $50(56.8)$ & & $429(48.2)$ & $182(56.0)$ & \\
\hline \multicolumn{10}{|l|}{ Sex } \\
\hline Female & 1107 (51.6) & $2078(43.5)$ & $<0.001$ & $643(57.1)$ & $30(34.1)$ & $<0.001$ & $515(57.9)$ & $158(48.6)$ & 0.004 \\
\hline Male & $1037(48.4)$ & $2702(56.5)$ & & $483(42.9)$ & $58(65.9)$ & & $374(42.1)$ & $167(51.4)$ & \\
\hline \multicolumn{10}{|l|}{ Age } \\
\hline Younger & 1049 (48.9) & $1280(26.8)$ & $<0.001$ & $425(37.7)$ & $37(42.0)$ & 0.4 & $359(40.4)$ & $103(31.7)$ & 0.006 \\
\hline Older & $1094(51.0)$ & $3468(72.5)$ & & $701(62.2)$ & $51(58.0)$ & & $530(59.6)$ & $222(68.3)$ & \\
\hline Unknown & $1(0.0)$ & $33(0.7)$ & & & & & & & \\
\hline \multicolumn{10}{|l|}{ Had skills assessment } \\
\hline Yes & $743(34.6)$ & $1739(36.4)$ & 0.2 & $293(26.0)$ & $9(10.2)$ & 0.001 & $206(23.2)$ & $96(29.5)$ & 0.02 \\
\hline No & $1401(65.3)$ & $3042(63.6)$ & & $833(74.0)$ & 79 (89.8) & & $683(76.8)$ & $229(70.5)$ & \\
\hline \multicolumn{10}{|l|}{ Specialty type } \\
\hline Family medicine & $880(41.0)$ & - & $<0.001$ & 817 (72.6) & $35(39.8)$ & $<0.001$ & $672(75.6)$ & $180(55.4)$ & $<0.001$ \\
\hline Specialist & $1264(59.0)$ & - & & $309(27.4)$ & $53(60.2)$ & & $217(24.4)$ & $145(44.6)$ & \\
\hline No postgraduate position & - & $4781(100.0)$ & & & & & - & - & \\
\hline \multicolumn{10}{|l|}{ First rank } \\
\hline Resident & - & - & - & $1071(95.1)$ & $52(59.1)$ & $<0.001$ & 865 (97.3) & $258(79.4)$ & $<0.001$ \\
\hline Fellow & - & - & & $55(4.9)$ & $36(40.9)$ & & $24(2.7)$ & $67(20.6)$ & \\
\hline
\end{tabular}




\section{OPEN}

Research

graduate training program between 2005 and 2009 or had first entered a specialty postgraduate training program in 2005 or 2006. Most of these physicians had passed the Qualifying Examination Part II (1126 [92.8\%]) and had obtained a specialty designation (889 [73.2\%]) (Table 1).

Compared to graduates who did not pass the Qualifying Examination Part II, a larger proportion of graduates who passed the examination were women, had participated in a skills assessment/training program, were in a family medicine program and were a resident $(p<0.01)$ (Table 2$)$. After other significant predictors were controlled for, men were 0.44 (95\% CI $0.27-0.73)$ times as likely as women to pass the examination (Table 3). Younger graduates were 0.53 (95\% CI 0.31-0.90) times as likely as older graduates to pass the examination. Those who had participated in a skills assessment/ training program were 3.80 (95\% CI 1.75-8.26) times more likely to pass the examination than those who had not. Fellows were 0.05 (95\% CI 0.03-0.09) times as likely as residents to pass the examination.

Compared to graduates who did not obtain a specialty designation, a larger proportion of graduates who obtained a specialty designation were women, were younger, had not participated in a skills assessment/training program, were in a family medicine program and were a resident $(p<0.01)$; a smaller proportion were non-Canadian graduates from other medical schools $(p=0.01)$ (Table 2$)$. After other significant predictors were controlled for, men were 0.74 (95\% CI 0.56 $0.96)$ times as likely as women to obtain a specialty designation (Table 3). Those who had participated in a skills assessment/training program were 0.65 (95\% CI 0.48-0.89) times as likely to obtain a specialty designation as those who had not. Family medicine trainees were 0.59 (95\% CI 0.44-0.80)

\begin{tabular}{|c|c|c|c|}
\hline \multirow[b]{2}{*}{ Variable } & \multicolumn{3}{|c|}{ Milestone; OR (95\% Cl) } \\
\hline & $\begin{array}{l}\text { Obtained } \\
\text { postgraduate } \\
\text { position }\end{array}$ & $\begin{array}{l}\text { Passed Qualifying } \\
\text { Examination Part II }\end{array}$ & $\begin{array}{l}\text { Obtained specialty } \\
\text { designation }\end{array}$ \\
\hline \multicolumn{4}{|l|}{ Sex } \\
\hline Female & 1.00 & 1.00 & 1.00 \\
\hline Male & $0.74(0.66-0.82)$ & $0.44(0.27-0.73)$ & $0.74(0.56-0.96)$ \\
\hline \multicolumn{4}{|l|}{ Age } \\
\hline Younger & $1.77(1.57-2.00)$ & $0.53(0.31-0.90)$ & NS \\
\hline Older & 1.00 & 1.00 & NS \\
\hline Unknown & $0.03(0.04-0.22)$ & - & NS \\
\hline \multicolumn{4}{|l|}{ Had skills assessment } \\
\hline No & 1.00 & $3.80(1.75-8.26)$ & $0.65(0.48-0.89)$ \\
\hline Yes & $1.15(1.02-1.29)$ & 1.00 & 1.00 \\
\hline \multicolumn{4}{|l|}{$\begin{array}{l}\text { Type of international medical } \\
\text { graduate }\end{array}$} \\
\hline $\begin{array}{l}\text { Canadian graduate of Western or } \\
\text { Caribbean medical school }\end{array}$ & $4.69(3.82-5.71)$ & NS & NS \\
\hline $\begin{array}{l}\text { Canadian graduate of other } \\
\text { medical school }\end{array}$ & $1.49(1.31-1.70)$ & NS & NS \\
\hline $\begin{array}{l}\text { Non-Canadian graduate of } \\
\text { Western or Caribbean medical } \\
\text { school }\end{array}$ & $0.96(0.70-1.32)$ & NS & NS \\
\hline $\begin{array}{l}\text { Non-Canadian graduate of other } \\
\text { medical school }\end{array}$ & 1.00 & NS & NS \\
\hline \multicolumn{4}{|l|}{ Specialty type } \\
\hline Family medicine & NS & NS & $0.59(0.44-0.80)$ \\
\hline Specialist & NS & NS & 1.00 \\
\hline \multicolumn{4}{|l|}{ First rank } \\
\hline Resident & NS & 1.00 & 1.00 \\
\hline Fellow & NS & $0.05(0.03-0.09)$ & $0.16(0.09-0.26)$ \\
\hline
\end{tabular}


times as likely as specialist trainees to obtain a specialist designation. Fellows were 0.16 (95\% CI 0.09-0.26) times as likely as residents to obtain a specialty designation.

\section{Interpretation}

Canadians who studied abroad were more likely than other international medical graduates to obtain a postgraduate position but did not perform better than other graduates in subsequent milestones. The findings support initiatives to treat all international postgraduate applicants fairly, ${ }^{22}$ without distinguishing citizenship or permanent residency status before medical school training.

A sizeable proportion (4.6\% [52/1123]) of international medical graduates in residency programs did not pass examinations (up to $6 \mathrm{yr}$ after being admitted to a program) to obtain the Licentiate of the Medical Council of Canada credential, and almost 1 in 4 (258/1123) did not obtain a specialty designation to qualify for full licensure. Moreover, although fellows were less likely than residents to have passed the Qualifying Examination Part II or have obtained a specialty designation, $60.4 \%(55 / 91)$ passed the examination and $26.4 \%(24 / 91)$ obtained a specialty designation. We do not know whether international medical graduates had withdrawn from their postgraduate training program or did not take or failed either the Qualifying Examination Part II or the specialty examination, because these data were not reported to the National IMG Database. Residents may choose not to take the examination since they are able to practise without a specialty designation (usually under a provisional license $)^{23}$ or if they do not intend to practise in Canada. These findings highlight the need to identify and address training issues of international medical graduates in postgraduate programs. Successful residency training is critical for integrating immigrant international medical graduates into Canadian practice and, more broadly, immigrants into Canadian society and relates to the social accountability goals of medical schools. ${ }^{22}$ These findings also suggest that fellowships may offer an alternative route for some international medical graduates to qualify for licensure in Canada.

Compared to international medical graduates who had not participated in a skills assessment/training program, those who had participated in such a program were more likely to obtain a postgraduate training position and to pass the Qualifying Examination Part II but less likely to obtain a specialty designation. These programs are an admission requirement in some provinces, which may help explain why program participants were more likely to obtain a postgraduate position. However, participation in these programs does not identify physicians who will perform well in the longer term in their training program. Similarly, younger graduates, who were more likely than older graduates to obtain a postgraduate position, may fare poorly on the Qualifying Examination Part II because they lack the clinical experience of their older counterparts. These findings highlight the need to identify selection criteria for postgraduate programs that are fair and transparent and that identify candidates who will perform well and qualify for licensure. The National Assessment Collaboration Examination was introduced after the period covered by the National IMG Database.

\section{Limitations}

Given the sequential nature of examinations, we were unable to analyze a single cohort from the start (Evaluating Examination) to obtaining a specialty designation. Recent data show that Canadians who studied abroad continue to obtain most postgraduate positions available to international medical graduates. ${ }^{24}$ Throughout our analyses, we assumed that all international medical graduates who realized 1 milestone would attempt to realize the subsequent milestone. Since faculties of medicine report the legal status of international medical graduates in postgraduate programs, we were unable to identify potential visa trainees or fellows prospectively in our first cohort. As a consequence of these limitations, the analyses underestimate rates of milestone realization by overinflating denominators.

\section{Conclusion}

A total of $31 \%$ of milestone-eligible international medical graduates obtained a postgraduate position, $93 \%$ passed the Medical Council of Canada Qualifying Examination Part II, and $73 \%$ obtained a specialty designation. Roughly 1 in 4 international postgraduate trainees did not obtain qualifications required for full licensure. Canadians who studied abroad were more likely than other international medical graduates to obtain a postgraduate position, but, once in a postgraduate program, there was no difference in realization of entry-to-practice milestones between the groups. These findings support policies that do not distinguish postgraduate applicants by citizenship or permanent residency status before medical school.

\section{References}

1. Doyle S. One-stop shopping for international medical graduates. CMAf 2010;182:1608.

2. Buske L. International medical graduates in Canada. Ottawa: Canadian Medical Association; 2008.

3. Canadian Post-M.D. Education Registry. The National IMG Database Report 2011. Ottawa: Association of Faculties of Medicine of Canada; 2011. Available: https://caper.ca/ assets/documents/2011_CAPER_National_IMG_ Database Report.pdf (accessed 2017 May 19).

4. Andrew R, Bates J. Program for licensure for international medical graduates in British Columbia: 7 years' experience. CMA7 2000;162:801-3.

5. Medical Council of Canada Qualifying Examination Part II: application and eligibility. Ottawa: Medical Council of Canada; 2016. Available: http://mcc.ca/ examinations/mccqe-part-ii/application-information/ (accessed 2016 Feb. 24).

6. Jiménez M. A star immigrant gives up on Canada. Globe and Mail [Toronto] 2005 Apr. 19; A1. Available: www.theglobeandmail.com/news/national/a-star -immigrant-gives-up-on-canada/article978811/?page=all (accessed $2017 \mathrm{Mar}$. 22).

7. International medical graduates and Canadians studying abroad. DataPoint! [Association of Faculties of Medicine of Canada]; 2012 Oct. Available: www. afmc.ca/pdf/datapoint/DATAPOINT-nov2012-Eng.pdf (accessed 2015 Feb. 20).

8. Thomson G, Cohl K. IMG selection: independent review of access to postgraduate programs by international medical graduates in Ontario. Vol 1: findings and recommendations. Toronto: Ontario Ministry of Health and LongTerm Care and Council of Ontario Universities; 2011. Available: www.health. gov.on.ca/en/common/ministry/publications/reports/thomson/v1_thomson.pdf (accessed 2016 Feb. 20).

9. Thomson G, Cohl K. IMG selection: independent review of access to postgraduate programs by international medical graduates in Ontario. Vol 2: analysis and background. Toronto: Ontario Ministry of Health and Long-Term Care and Council of 
Ontario Universities; 2011. Available: www.health.gov.on.ca/en/common/ministry/ publications/reports/thomson/v2_thomson.pdf (accessed 2016 Feb. 20).

10. Truscott A. Moratorium urged for foreign visa trainees. CMA7 2008;179:638-9.

11. Wong A, Lohfeld L. Recertifying as a doctor in Canada: international medical graduates and the journey from entry to adaptation. Med Educ 2008;42:53-60.

12. Banner S, McKiver A, Rattanasithy S, et al. Canadian students studying medicine abroad. Ottawa: Canadian Residency Matching Service; 2010. Available: www. carms.ca/pdfs/2010_CSA_Report/CaRMS_2010_CSA_Report.pdf (accessed 2017 May 19).

13. Buske L. Number of "Canadian IMGs" seeking residency training soars. Ottawa: Canadian Collaborative Centre for Physician Resources, Canadian Medical Association; 2010.

14. Szafran O, Crutcher RA, Banner SR, et al. Canadian and immigrant international medical graduates. Can Fam Physician 2005;51:1242-3.

15. BC Ministry of Health/BC Ministry of Advanced Education/UBC Faculty of Medicine. International medical graduate program (IMGBC) challenges facing Canadians studying abroad [briefing document]. Vancouver: Faculty of Medicine, University of British Columbia; 2011.

16. Canadian Post-M.D. Education Registry. IMGs in Canada project: the Pearson Conference. Data and analysis plan. Ottawa: Association of Faculties of Medicine of Canada; 2008.

17. Instruction manual. 13th ed. [revised 2016]. Ottawa: Canadian Post-M.D. Education Registry; 2015.

18. MacLellan AM, Brailovsky C, Rainsberry P, et al. Examination outcomes for international medical graduates pursuing or completing family medicine residency training in Quebec. Can Fam Physician 2010;56:912-8.

19. 2011-2012 annual census of post-M.D. trainees. Ottawa: Canadian Post-M.D. Education Registry; 2012. Available: https://caper.ca/ assets/documents/ pdf_2011-12_CAPER_Census.pdf (accessed 2017 May 19).

20. Hall P, Keely E, Dojeiji S, et al. Communication skills, cultural challenges and individual support: challenges of international medical graduates in a Canadian health care environment. Med Teach 2004;26:120-5.

21. Tabachnick BG, Fidell LS. Using multivariate statistics. 4th ed. Toronto: Allyn and Bacon; 2000.

22. Fleming $\mathrm{P}$, Mathews $M$. Retention of specialist physicians in Newfoundland and Labrador. Open Med 2012;6:e1-9.

23. Best Practices in Applications and Selection Working Group. Best practices in applications \& selection: final report. Toronto: Postgraduate Medical Education, University of Toronto; 2013. Available: http://pg.postmd.utoronto.ca/
wp-content/uploads/2016/06/BPASDraftFinalReportPGMEACMay2013.pdf (accessed 2017 May 19).

24. By the numbers: highlights from the $2015 \mathrm{R}-1$ main residency match. Ottawa: Canadian Resident Matching Service. Available: www.carms.ca/en/data-and -reports/r-1/2015-r-1-highlights/ (accessed 2016 Aug. 29).

Affiliations: Division of Community Health and Humanities (Mathews, Yi), Faculty of Medicine, Memorial University of Newfoundland, St. John's, Nfld.; Canadian Post-M.D. Education Registry (Kandar), Association of Faculties of Medicine of Canada; Royal College of Physicians and Surgeons of Canada (Slade); Health Canada (Beardall); Telfer School of Management (Bourgeault), University of Ottawa, Ottawa, Ont.

Contributors: Maria Mathews conceived of the study, led the data analysis, and drafted and revised the manuscript. Rima Kandar obtained the data. All of the authors contributed to the study design and data analysis and interpretation, approved the final version to be published and agreed to act as guarantors of the work.

Funding: This study was funded by grant MOP 137069 from the Canadian Institutes of Health Research, with in-kind contributions from the Canadian Post-M.D. Education Registry.

Disclaimer: The opinions expressed in this article are those of the authors alone and not of the Canadian Post-M.D. Education Registry, Health Canada or the Royal College of Physicians and Surgeons of Canada.

Acknowledgements: The authors are grateful to Lynda Buske for facilitating access to Canadian Post-M.D. Education Registry staff, providing advice regarding data, and reviewing the analyses and manuscript drafts. They thank Les Forward for linking data in the database and for providing advice regarding coding.

Supplemental information: For reviewer comments and the original submission of this manuscript, please see www.cmajopen.ca/content $/ 5 / 2 /$ E476/suppl/DC1 